\title{
Catalogue of the Emblems of Saints
}

\section{Hart}

To cite this article: C. Hart (1844) Catalogue of the Emblems of Saints, Archaeological Journal, 1:1, 53-63, DOI: $10.1080 / 00665983.1844 .10850517$

To link to this article: http://dx.doi.org/10.1080/00665983.1844.10850517

曲 Published online: 10 Jul 2014.

Submit your article to this journal $\pi$

Q View related articles $₫$ 


\section{CATALOGUE OF THE EMBLEMS OF SAINTS.}

OF THE XIT. ARTYCLES OF TEE FAYTHE. Ga. $X \nabla$.

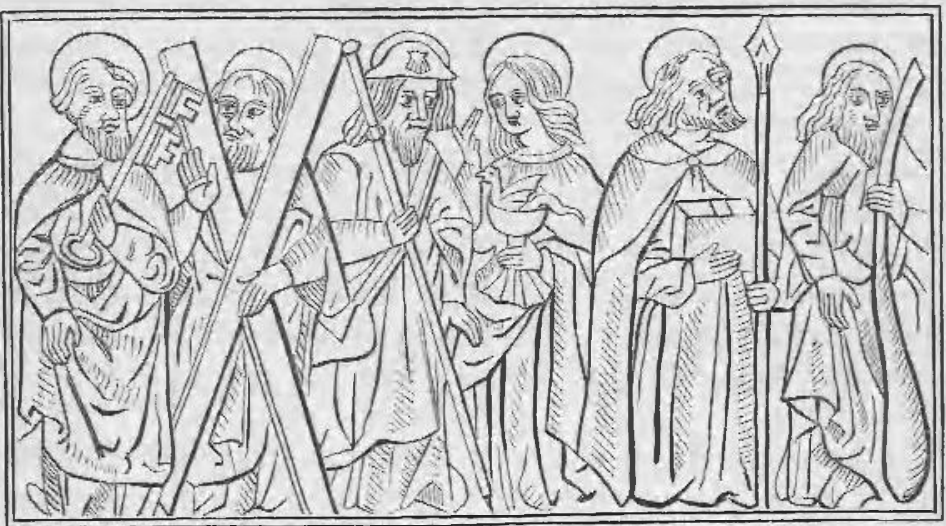

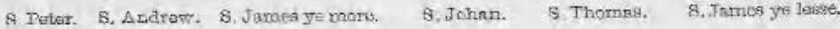

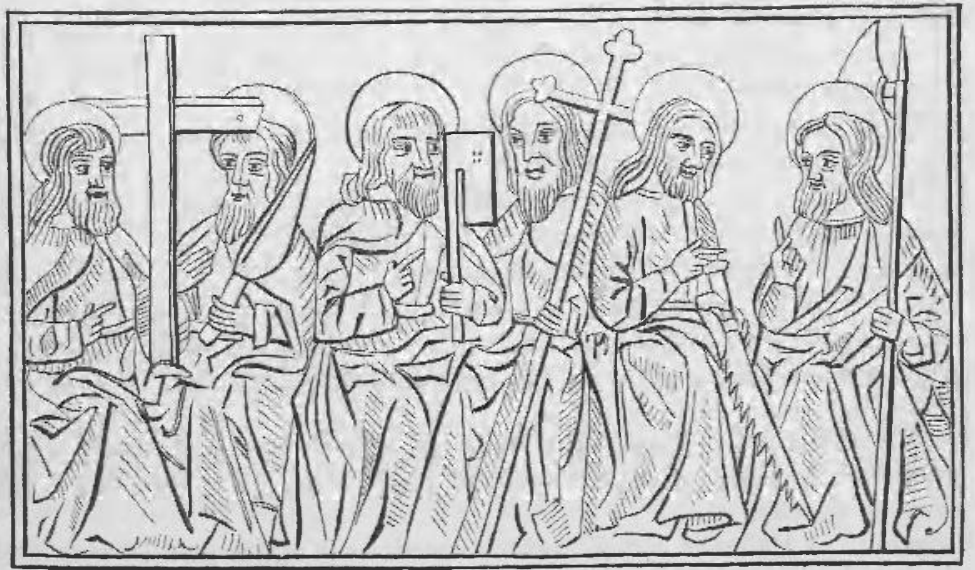

S. Phylyppe. S. Barthylmew. S Mathewe. S Symon. 53.Jude. S. Mathyas. 
IT is the object of the following catalogue to supply a clue to the practical antiquary in his interpretation of ancient art, where, but for this sacred heraldry, he must have worked in the dark. In the middle ages, pictures were the books of the unlearned; and those who were unable to read, could at once recognise a Saint by his appropriate emblem. The memory of these things has long since faded away in our country; but illuminated manuscripts, painted glass, the paintings which decorate the screen-work or walls of many of our churches, monastic seals, and early wood-engravings, furnish us with the means of resuscitation.

Saints of the highest order had a double feast, or nine lessons assigned to them in the Breviary, so that the reader may easily ascertain to which he ought to give a preference in cases of doubt. When the same emblem belongs to many Saints of the same denomination, an asterisk (*) is prefixed to the emblem as a caution, that he may not too hastily appropriate.

The following abbreviations have been employed throughout, to which are here added the vestments belonging to each order, as a means of distinguishing from each other different Saints who had the same emblem.

A. Abbot or Abbess, commonly dressed like an ordinary monk or nun, (see C.) but with a crosier in the right hand and a book in the left. On seals (and perhaps sometimes in paintings,) Abbots have a Mitre, Chasuble, Dalmatic, and other insignia of a Bishop.

Ap. Apostle, usually without any tonsure, a long beard, a close tunic and mantle. At an early period the feet are usually bare.

Abp. Archbishop, like a Bishop (see Bp.) but with the pall over the Chasuble, and a Cross-staff in the left hand, instead of a Pastoral-staff.

Bp. Bishop. A Mitre, Crosier (or pastoral staff) in his left hand, blessing with the right, or holding a book. Vested in the Chasuble, Maniple, Dalmatic, Tunic, Stole, Alb, and Amess. Sometimes a Bishop wears a Cope over a Dalmatic and Alb; sometimes a Mozzetta, Rochet, and Alb, but the latter very rarely.

C. (Conobite) Monk or Nun. The Monk has a frock, cowl, and usually a scapular; the Nun a frock, often a scapular, and a close fitting kerchief or veil, corering the chin.

D. Deacon. A Dalmatic, a Stole, (which sometimes is represented as worn over the left shoulder ;) a Maniple, Amess, and Alb.

E. Evangelist, like an Apostle. (See A.)

H. Hermit, like a Monk, but with a long beard. Commonly he has a scull before him, and large beads hanging at his girdle: sometimes he is clad in skins of beasts. 
K. King. A Crown, Sceptre, Ball and Cross, (or Mound,) and the other wellknown insignia of royalty.

M. Martyr. Usually dressed in the vestments belonging to his rank in the Church, with the emblem of his martyrdom in his right hand, and a palm-branch in his left.

P.P. (Pater Patrum) Pope. Triple Crown, triple Cross-staff, and Cope.

P. Priest. Vested in the mass-vestment, composed of the Chasuble, Maniple, Stole, Amess, Alb.

V. Virgin. Commonly as a young woman with flowing hair: sometimes as a Nun. (See C.)

W. Widow. An aged woman, wearing a mantle, a kerchief or veil, and wimple covering the chin, resembling the attire of a Nun.

The reference to the day of the Saint's anniversary may be considered as an index not only to the various Breviaries, but to nearly all the collections of the lives of Saints that have been published. In every instance that occurs to my recollection, the legends are inserted according to the place which they occupy in the order of the year: so that the reader may refer to them without any difficulty, in case of his wishing to understand the rationale of any particular emblem.

The chief work to which reference may be made with advantage for information regarding the legends of Saints, is the Acta Sanctorum, in which they are found arranged according to the order of the year: this great work, comprised in fiftythree folio volumes, extending only to October, comprises a mass of valuable historical materials, and dissertations on numerous subjects connected with sacred antiquities. A continuation of this work is now in progress in the Netherlands. The Acta of the Saints of the Benedictine Rule, edited by Mabillon, are exceedingly valuable, and afford authentic evidences for the early history of Great Britain, which are not published elsewhere. The numerous versions of the Golden Legend, by Jacob de Voragine, are well known; the rare early edition by Wynkyn de Worde, presents many little wood-cut figures of Saints, and some of the French editions are more fully illustrated in this manner. The Nova Legenda Anglioe of John Capgrave is the most important authority as regards English Hagiography, and the Liber Festivalis may be consulted with advantage. The most curious relations, however, illustrative of the usages of the Church, of history, and of manners, are still to be found only in the MSS. preserved in our public libraries. Many compilations have been published in various countries which may be found useful; such as the 
Lives of the Saints, by Alban Butler; Petri de Natalibus Catalogus Sanctorum, Lugd. 1542; Harcei Vitce Sanctorum, Antw., 1690; and Grassii Vitae Sanctorum, Cologne, 1616. With respect to the Roman Breviary, preference should be given to the editions which were printed before the Council of Trent; and with reference to the Saints of any particular country, to the local Breviaries.

\section{RULES OF APPROPRIATION.}

1. In cases of doubt, recollect that the $\Lambda$ postles, the most popular Saints in the Christian world, and in that particular country or neighbourhood, the patron Saint of the Church itself, or those whose reliques are known to have been deposited there in ancient times, are more likely to have been depicted than others. In addition to which I would remark, that connected with some Churches, there were guilds dedicated to particular Saints.

2. When two or more Saints bear the same emblem, those who are most popular ought to have the benefit of the doubt: and observe carefully the quality of the Saint; whether he was a Bishop, Abbot, or so forth, for this will often supply a certain criterion.

3. Observe well the juxtaposition, for this will be often a clue to your interpretation. Thus, if you discover two or three Apostles, you may reasonably expect to find the others also.

4. In applying this catalogue to the interpretation of anrient art, abstract as much as possible the emblem from its unimportant circumstances, making a logical distinction between the proprium and the accidens. Even in cases where they rigorously adhered to the ancient symbolism, the painters varied considerably in the detail. Of this many examples could be given. The same martyr is sometimes represented as transfixed with arrows, and sometimes he bears an arrow in his hand.

5. We have no reason for supposing that the inferior Saints (many of whom were martyred in exactly the same way) had any emblem exchusively assigned to them. In early printed books, (the Legenda Aurea, for example,) the same wood-cut is 
continually repeated; but Saints of this order would scarcely be represented except in places where they had a local interest, discoverable by county history or the tradition of the neighbourhood.

6. Ancient paintings in fresco, on panel, or glass, and manuscript illuminations, have of course an authority which cannot belong even to the earliest wood-cuts; as the artist had not the same temptation to generalise or repeat. Nevertheless, many of these early wood-cuts were unquestionably designed after more ancient models on panel, glass, \&c., and where they can be identified by their circumstances are of very great value.

Almsgrving . . Female employed in distributing alms . . St.Potentiana ",V.May 19 Altar . . . . Martyrdom of a Pope at the Altar . . . St. Stephen, P.P. Aug. 2 *Altar .... Martyrdom of a Bishop at the Altar .. $\left\{\begin{array}{c}\text { St. Thomas a Becket } \\ \text { Dec. } 29\end{array}\right.$ Altar . . . . King lying at the foot of an Altar . . . St. Canute, K.M.July 10

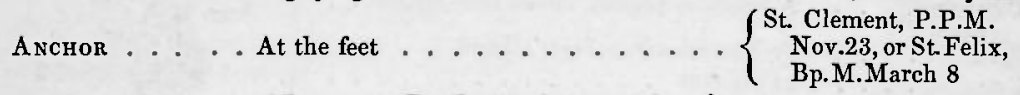
ANGEL ..... $\left.\begin{array}{c}\text { In armour, Devilat the feet, sometimes } \\ \text { other Angels behind .............. }\end{array}\right\}$ ANGEL and BoY . Walking together, (see book of Tobit) . $\left\{\begin{array}{c}\text { Raphael the Archangel, } \\ \text { Uct. } 24\end{array}\right.$ (St.George, M. April 23,

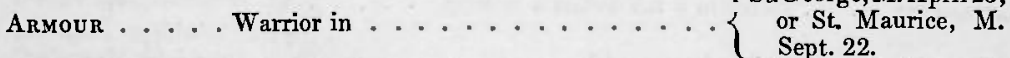

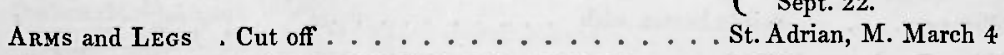
*Arrow or Spear. In hand, sometimes the emblem of . . . St. Thomas, Ap. Dec. 21

*Arrow \& Book. In hand ............ St. Ursula, V.M. Oct. 21 Arrows ..... Saint stripped, and transfixed with .... $\left\{\begin{array}{l}\text { St.Edmund,K.M.Nov. } \\ 20 \text {, or St. Sebastian, } \\ \text { M. Jan. 20 }\end{array}\right.$ Banner \& Cross . Seen in the air ........... . St.Constantius ${ }^{c}$,Emperor BASKET . . . . . Held in the hand, containing bread . . . St. Philip, Ap. May 1 Basket . . . . O Of Fruit, Flowers, and Spices in hand . . St. Dorothy, V. M. Feb. 6 pFn ..... $\left.\begin{array}{c}\text { Two Physicians attending a Bishop in } \\ \text { Bed ................. }\end{array}\right\}\left\{\begin{array}{c}\text { St. Cosmas and St. Da- } \\ \text { mian, M. Sept. } 27\end{array}\right.$ BeEHIVe .... In the back ground ........ St. Ambrose, Bp. Dec. 7 Blind MaN . . . Restored to sight, by a Saint ..... St. Magnus, M. Aug. 19 BLock . . . . . Saint kneeling at, the sun rising . . . . St. Waltheof

*Block . . . . A Pope kneeling at the ....... St. Fabiand,P. P. M. \&c.

Probably other Saints thus.

b Several of the Saints were martyred thus.

c It seems probable that this is an error, and that the Emperor Constantine was really intended. d A great many Martyrs are represented at the 
BoAT or SHIP . . Held in the hand

St. Jude, Ap. ${ }^{\text {e, Oct. } 28}$

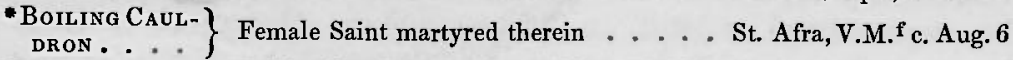

Book. . . . . A Female with a Book, teaching a Child. St. Anneg, July 26

Воoк...... \{ King, holding the Gospel of St. John $\{$ St.Edward, K.Confes-

Books ... . Bishop, holding three. . . . . . . St. Hilary, Bp. Jan. 13

Books . . . . . Burning before a Saint, who holds a sword. St. Dominick, C. Aug. 4

*Book \& Crosier. The former in right hand, the latter in left . St. Bridget ${ }^{b}$, V. C. Feb.1.

Botтle .... Two figures holding a bottle and shears . \{ St. Cosmas an $1 \subseteq t$. Da-

\{ $\operatorname{mian}^{1}$, M. Sept 27.

Bowels .... Wound round a windlass or a staff ... $\{$ St Erasmus, Bp. M.

Bow and ARrow. Held by a Man, aiming at a naked Virgin St.Christina, V. July 24

Box of SpIKenard. In the hand of a Female ...... I St. Mary Magdalene,

Bread ..... A loaf in the hand of a Female .... $\begin{gathered}\text { July } 22 \\ \text { St. Gertrule, v. a 1d } \\ \text { Abbess. March } 17 \mathbf{k}\end{gathered}$

Breast .... Torn by pincers, or Breasts in a dish .. St. Agatha, V. M. Feb. 5

Bull or Bulls. . Dragging a Saint over a stony place - St. Saturninus, May 2

CAnde .... In the hand .......... St. Genevieve, V. Jan. 3

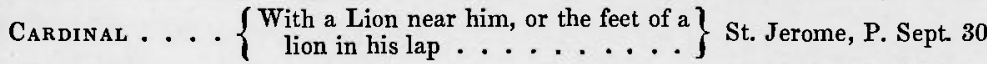

CarPenter's
Sevare ... In the hand ....................

* Cauldron ... A Saint boiled in .......... $\begin{gathered}\text { St ohn Port Lat. Ap. } \\ \text { M } 6\end{gathered}$

Chains .... A figure in prison, loaded with fetters .. \{ St. Peter ad Vincula,

Chains .... Or Manacles in a Saint's hand .... St. Leonard, C. Nov. 6

Chalice. . . . At the feet ......... St. Richard, Bp. April 3

Chalice or CuP . With a winged Serpent issuing from it . . St. John, Ap. Dec. 27

ChILd . . . . In the arms ........... St. Britius, Bp. Nov. $13^{1}$

CHILD..... $\left.\begin{array}{c}\text { With a glory round the head, and a } \\ \text { spoon in the hand, before a Bishop }\end{array}\right\}$ St. Augustine, Bp.Aug.28

Children . . . Three in a tub before a Bishop . . . . St. Nicholas, Bp. Dec. 6

... $\left\{\begin{array}{l}\text { St. Boniface, Abp. M } \\ \text { June } 5, \text { St Maccabea }\end{array}\right.$

Cuvb.....................

Сомв ...... A wool-comb in the hand ...... St. Blaise, Bp. M. Feb. 3

Confessional . . A Bishop seated in ........ St. Gothard, Bp. May 4

Cross ..... With single transverse bar ....... A Primate or Metropolitan

Cross ..... With triple bars .......... A Pope

Cross ....................... K Knight Hospitaler of

2. $\{$ St. J hn of Jerusalem

Cross ..... Inverted, a Saint thus crucified .... St. Peter, Ap. June 29

Cross . . ... Saltier $\mathbf{X}$, a Saint leaning on ..... St. Andrew, Ap. Nov. 30

Cross .... . Saltier in background . . . . . . . St. Benignus, D. June 6

Cross .... . . Like a $\mathbf{T}$ and a spear or double cross $\ddagger$. . St. Philip, Ap. May 1

- He and St. Matthew are sometimes represented with clubs in their hands.

f Other martyrdoms are so represented, particularly St. John the Evangelist.

B Sometimes on this Book are the words " Radix Jesse fioruit." b Many Bishops and Saints are represented with Books.

I See BED, supra.

N.B. There is another Gertrude, V. Nov. 15.

1 Simeon and the B. V. M. are thus represented. 
Cross..... A large one in the arms $\left\{\begin{array}{c}\text { St. Helena, Empress, } \\ \text { Aug. 18 }\end{array}\right.$

Cross ..... A A tall one, with a bell at the top, 1

Crowned Figure $\{$ Tnt

Cups .... Two cups or goblets ........ St. Odilo, Abbot, Dec. 31

DEAD ..... Raised to life . . . . . . . St. Marcialis, Bp. July 2

*Devir ... Beating a Saint with a club .... St.Apollinaris, July 23; a ouners

*Devils.... Saints, tormented by

S St. Lucy, V.M. Dec. 13;

$\{$ and many others

Doe or Hind . . . Crouching near an Abbot . . . . . . St. Giles, A. Sept. 1

Dog ...... Setting a globe on fire. . . . . . . St. Dominick m, C. Aug. 4 (Seated near a Saint, with a loaf in his)

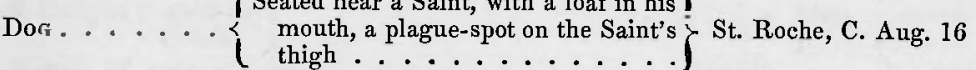

Dove ..... Lighting on the head ........ St. Eunuchus ${ }^{\text {, }}$, c. July 15

Dove .... Bringing a letter ......... St. Oswald, K. Aug. $5^{\circ}$

Doves..... In a basket, and staff in the hand.... St. Joachim, April 16

Dragon .... Under the feet of an armed figure . . . . St. George, M. April 23

Dragon .... \{ Under the feet, and spear with a cross \} I St. Margaret, V.M.July

EAGLE..... Standing by the side .......... $\left\{\begin{array}{l}\text { St. Joh } 1, \text { EvangelistP, } \\ \text { Dec. } 27\end{array}\right.$

Expositorium . . Of Blessed Sacrament in the hand . . . . St. Clare, V. Aug. 12

Espousals ... To the Saviour........... St. Catharine of Sienna,

FACE .... $\begin{gathered}\text { Of the Saviour upon a cloth or }\} \text { St. Veronica, Sept. } 9 \\ \text { kerchiet, usually called the Vernacle }\}\end{gathered}$

Faldstool ... A mitred Figure kneeling at a . . . . St. Ambroseq, Bp. Dec. 7

$\left.\begin{array}{c}\text { FaWN, or rather } \\ \text { ANTEL OPE. }\end{array}\right\}$ At a king's feet........... St. Henrv VI., K.

FAwn or DoE . . Before a Female, who holds a cross . . . St. Withburga, V. C.

Female . . . . With a Devil taking her hand . . . . St. Theodora, C. Nov. 22

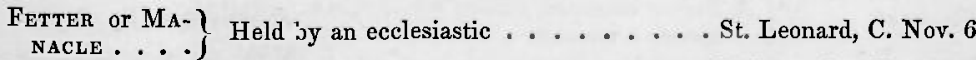

Fire ...... A Saint lighting a ........ St.Januarius, Bp. Sept. 19

Fish . . . . Held in the hand; sometimes two . . . St. Simon, Ap. Oct. 28

*Floggina. . . A Saint scourged to death with rods . . \{ $\begin{aligned} & \text { St. Regina, St. Gol gon, } \\ & \text { St. Theodore \&c. }\end{aligned}$

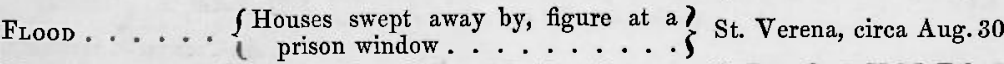

Flower . . . . In one hand, and Sword in the other . . . St. Dorothyr, V.M. Feb. 6

Fuowers. . . . Sprouting from the neck, head in hand . . St. Flora, V. M. June 15

FruIT . . . . An animal eating at the feet of a Saint . . St. Mangen, circa Sept. 6

Fuller's Bat ... In the hand ......... $\begin{gathered}\text { St. James the Less, Ap. } \\ \text { May } 1\end{gathered}$

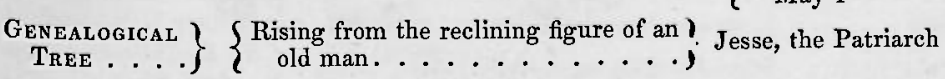

m See Books, supra.

n The Blessed Virgin and many Saints thus.

- A Dooe whispering in the ear of a figure with a triple crown is a common symbol of a Pope.The Dove breathing into the ear of a Pope is generally a symbol of Pope Gregory the Great.

P See CHAL IC E, supra.

q See BEE-HIVE, supra.

r See Bas ket, supra. 
GIANT .....

(Carrying the infant Saviour on his shoulder, across a river; he leans on a rude staff, which often is represented as bursting into leaf; a Hermit usually in the distance with a lantern ..........

St.Christopher, M.July 25

Goat ..... Satan appearing in the form of ... $\begin{gathered}\text { St. A thor } y, t \text { the } \\ \text { mit Jan } 17\end{gathered}$

SSt. A ithor $y$, the Her-

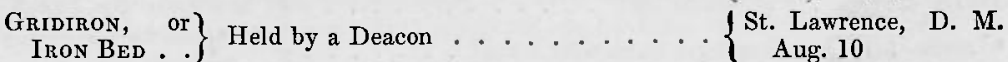

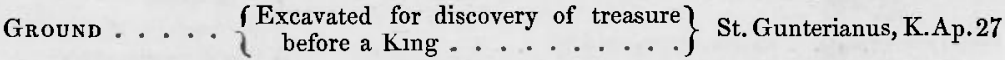

Hairy Man . . Wearing a crown, before a double cross . St. Onofrius, June 11

Halbert. . . . In his hand, sabre by his side . . . . . St. Theodore, M. Nov. 9

HAMMER \& ANvil. In one hand, sword in the other . . . . St. Adrian, M. March 4

HAMMER and In his hands........ \{ St Eloy, (Eligius) B.

Crosier... $\}$ In his hands.......................

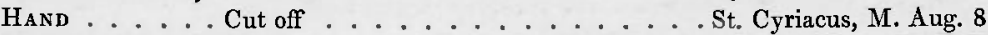

HARP ..... Figure playing on the ...... \{ $\begin{aligned} & \text { St.Cecilia,V.M.Nov.22, } \\ & \text { St.Dunstan,Abp.May }\end{aligned}$

BERT, or B AT- $\}$ In the hand .......... St. Matthias, Ap. ${ }^{\mathrm{s}}$ Feb. 24

TLE-AXE . .

HeAD ..... Carried in the hands ....... $\begin{aligned} & \text { St. Denys, Abp. M. Oct. } \\ & 9, \text { St. Winifred, V. M. }\end{aligned}$

$\left\{\begin{array}{l}9, \text { St. W } \\ \text { Nov. } 3\end{array}\right.$

HeAD . . . . Carried in a dish or charger . . . . . . St. John Baptist, Aug. 29

HEAD ..... Of King Oswald in his hand .... St.Cuthbert, Bp. March 20

HEAD ..... Of Goliah in the hand ....... . St. David the Psalmist

Heart . . . . . In the hand, or sometimes in the air . . . St.Augustine',Bp.Aug. 28

Hermi t . . . Kneeling, with beads in hand . . . . . St. Fiacre, C. Aug. 30

HILl. . . . . A Saint preaching on a . . . . . . St. David, Abp. March 1

HIND ..... r Wounded with an arrow. resting her ?

HIND ....

Horns ...... \{ Glory in that form, staff, and tables of $\}$

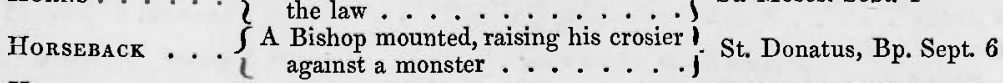

Horseback . . . Several mounted figures, one crowned . St. Maurice, M. Sept. 22

Host ..... A Bishop delivering it into a Man's hand. St. Lupus, Bp. July 29

IDOL . . . . . Falling from its pedestal ...... St. Philipu, Ap. May 1

Infants . . . Murdered by Soldiers. . . . . . . Holy Innocents, $\Gamma_{3} .28$

$\mathrm{K}_{E Y} \ldots \ldots\left\{\begin{array}{c}\text { One or two in his hand, the one fre- } \\ \text { quently of gold, the other of silver. }\end{array}\right\}$

St. Peter, Ap. June 29

Kings .... Three, with their gifts .......

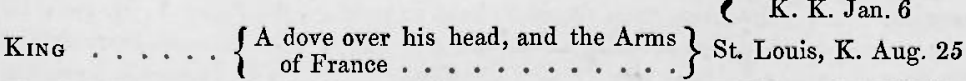

King's-HEAD. . . Guarded by a wolf . . . . . . . St.Edmund, K.M. Nov.20

KNIGIT ..... Armed on horseback, Dragon at his feet . St. Georgex, M. April 23

KNIFE ..... Figure holding one ......... St. Bartholomew, Ap.

LAdDer ..... (Emblem occurring in St. James' ?

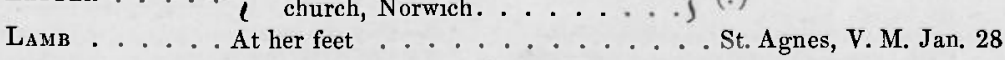

sany others are so represented.

See CHILD, supra.
"The same is introduced in the Flight into Egypt.

* See Armock, supru. 


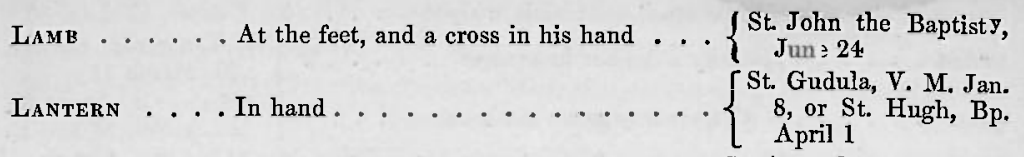

LEProus .... Spots on the body ........ St. Angradesma

LILY ..... In an Angel's hand ........ $\begin{gathered}\text { St. Gabriel, the Angel z, } \\ \text { March } 25\end{gathered}$

Libies ..... In a pot near the B. Virgin ..... $\begin{aligned} & \text { March } 25 \\ & \text { Blessed Virgin Mary, }\end{aligned}$

LIoN. ..... Lying near a Saint ........ $\begin{gathered}\text { St. Mark, Evangelist }{ }^{\text {a }} \text {, } \\ \text { April } 25\end{gathered}$

Lion...... See Cardinal

*Lions. . . . Crouching at a Saint's feet ...... St.Agapetus,M.Sept.17;

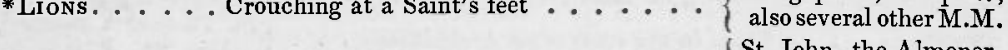

LOAF and ROSARY. In the hand

$\{$ St. John, the Almoner,

$\{$ Abp. Jan. 23

NaILs . . . . . In a boy's head and in his hand . . . . St. William ${ }^{\text {b }, ~ M . ~ M a r . ~} 24$.

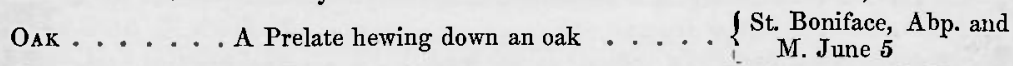

OıL ..... Distilling from the hand ...... St. Walburga, V. May 1

Organ. . . . Figure playing on the...... St. Cecilia, V.M. c Nov. 22

Ox...... Lying near him ......... \{ St. Luke, Evangelist,

Pastoral Staff. Fixed into a rock or tomb . . . . . . St. Wulstan, Bp. Jan. 19

PILGR IM . . . S Saint clad in slavine, with hat, bourdon, ? St. James the Great, Ap.

PrLarim... \{ staff, and escallop shell .... i \{ July 25

Pope. . . . . . On horseback, blessing the people . . . St. Leo, P. P. April 11

Pulpit .... Saint preaching from a ...... St. Maternus, St. Ru-

$\mathrm{R}_{\mathrm{ACK}} \ldots .$. Saint upon the rack ....... St. Vincent, M. Jan. 22

Raven. . . . . Bringing food to two Hermits . . . . . St. Paul, H. Jan. 10 or 15

Ring \& Sceptre. $\left\{\begin{array}{c}\text { In the hands, the former bestowed on } \\ \text { St. John Ev., disguised as a pilgrnm }\end{array}\right\}$ K. Edward. C. Jan. 5

River . . . . . Saint thrown into a river or a pit ... St. Vitalis, April 28

Rock ... . Saint embracing a rock ...... St. Rosalia, V. Sept. 4

Rods ..... A bundle of, in the hand ... . . . St. Faith, V. M. Oct. 6

SAracen .... Under the feet ......... St. Pancras, April 3

SAW . . . . A long saw in hand ....... St. Simon, Ap. d Oct. 28

Scales. . . . . Held by an Angel in armour, weighing souls. St. Michael e, Sept. 29

Scourge . . . . Held in a Prelate's hand . . . . . St. Ambrose, Abp. Dec. 7

*Sculr .... At feet, or in hand ....... St. Mary Magdalene

Scrtie .... In the hand ......... St. Walstan, Bp.

Seven Persons . Praying, or asleep in a cavern ..... $\begin{gathered}\text { Tle Ser en Sleepers, } \\ \text { July } 27\end{gathered}$

Shoemakers . . Two at work .......... $\{$ St. Crispin and St. Cris-

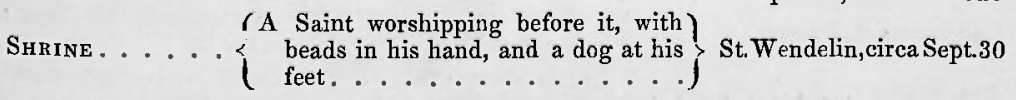

y See HEAD, supra.

It is peculiarly, if not exclusively, in the Annunciation that the archangel Gabriel is thus painted, appearing to the Virgin seated at a table.

at. Jerome is also attended by a Lion.

b Martyred by the Jews at Norwich. c See Haвр, supra.

d See Fish, supra.

- See Armour, supra.

f A Scull was common to all Hermits. The Magdalene generally bears her Box of SpikENARD, which see, supra. 
SPade . . . . In left hand, open book in right . . . . St. Fiacres, C. Aug. 30

SPEAr ..... Held by a Soldier in armour .... St. $\mathbf{L}$. $\mathrm{g}$ inu s, Soldier,

StAG .... With a cross between the horns ... $\begin{aligned} & \text { St.Hubert,Bp.Nov.3,St. } \\ & \text { Eustachius,M.May15 }\end{aligned}$

Stag ..... Crouching at a Prelate's feet ..... St. Aidan, Bp. Aug. 31

Stocks .... $\begin{gathered}\text { Persons confined in the stocks rescued } \\ \text { by a Saint .......... St. Leonard. Nov. } 6\end{gathered}$

Stones . . . . In the skirt or lap of a Prelate's chasuble . St. Alphage, Abp. Ap. 19

Stone . . . . . In his hand, or stones in his lap . . . . . St. Stephen, D.M.Dec. 26

Sun and Bird .. $\left\{\begin{array}{c}\text { The latter descending from the former, } \\ \text { upon a sleeping Saint .... St. Servatus, Bp. May } 13\end{array}\right.$

Sword . . . . In hand . . . . . . . . . . St. Paul, Ap. ${ }^{\mathrm{h}}$ June 29

Sword..... In hand, on some Norfolk screens . . . St. Matthias, Ap. Feb. 24

Sword . . . . Fixed in the scull of an Archbishop ... St. Thomas a Becket',

Sword . . . . Through his body as le stands at the Altar. St. Quiriacus, July 22

TABLE . . . . Ministering to Saints at a table . . . . St. Petronilla, May 31

Thorns . . . . Bishop dragged over . . . . . . . St. Mark, E. April 25

Tooth in Pincers. And Palm-branchk in the hand . . . . St. A pollonia, V.M. Feb. 9

Tower. . . . . In the hand ........... . St. Barbara, V. M. Dec. 4

Tre E.... $\begin{gathered}\text { Blossoming over the head of a female } \\ \text { as she sleeps ...... St. Etheldreda. June } 23\end{gathered}$

$\underset{\text { Shamoll }}{\text { Shamock. }}\}$ In a Bishop's hand ......... St. Patrick, March 17

Tub ...... Some liquid poured from, held over' ${ }^{1}$. . St. Alexius, July 17

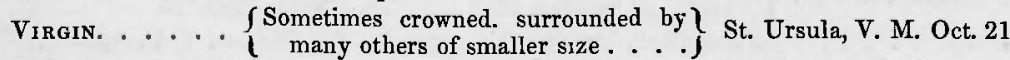

Virgin and Child Appearing from Heaven to a Saint . . . . St. Bernard, A. Aug. 20

WASHING ... Poor Men's feet .......... St.Louis, K.or St.Edith,

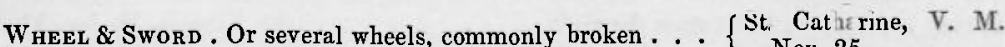

WoMAN .... Covered with her flowing hair .... $\begin{gathered}\text { Nov. } 25 \\ \text { Apry, theEgyptian }{ }^{m} \text {, }\end{gathered}$

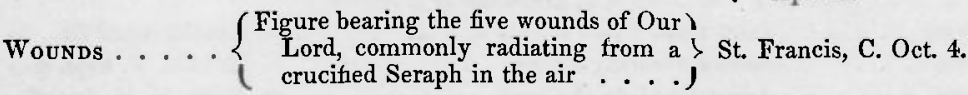

EMBLEMS OF FESTIVALS.

Dedic.tion of a Church . . Altar, with three men before it

FOUNDER OR BENEFACTOR . . Church in miniature, held in the hand

Invention of the Cross . . Cross lifted out of a tomb among spectators, May 3

Assumption of the Virgin . Virgin carried to Heaven by Angels, August 15

Exaltation of the Cross . King kneeling before a cross in the air, September 14

Corpus Christ ...... Shrine supported by two Men, or an Expository with

$\{$ the Eucharist carried in procession, May 31

( Three Men in purple, exactly alike-also, the Father as

Trinity ......... an old Man with triple crown, the Son as a young ( one, and the Holy Spirit as a dove

Catuedra S. Petri .... 4 A Pope seated, a nimbus surrounding his head; $\{$ Cardinals around him, February 22

I Angels release from a fiery gulph souls represented ALr Sours ........ $\begin{gathered}\text { Angels release from a fiery gulph } \\ \text { under the form of little children, Nov. } 2\end{gathered}$

- See Henмiт, supra.

b It is sometimes jagged like a saw.

i See Alta R, supra.

- A Palm-branch, as the general emblem of martyrdom, is often found with other Saints.
1 Dirty water thrown over him by his father's servants.

m She is often represented with a Monk standing before her. 


\section{CATALOGUE OF THE EMBLEMS OF SAINTS.}

\section{OF THE APOSTLES' MOST USUAL EMBLEMS.}

St. Peter, a key, or two keys, gold and silver, representing the keys of heaven and hellSt. Paul, a sword-St. Andrew, a cross saltier X-St. John, a chalice and serpentSt. Philip, a tau-cross, or a double cross, or spear ${ }^{\mathrm{n}}-$ St. Bartholomew, a butcher's knife-St. Thomas, an arrow or spear-St. Matthew, a club, a carpenter's square, or a money-box, to receive custom or tribute-St. James the Great, a pilgrim's staff, wallet, \&c.-St. James the Less, a fuller's bat and saw-St. Jude, a boat in his hand or a club-St. Simon, a fish or fishes in his hand, and sometimes a saw-St. Matthias, a hatchet, battle-axe, or sword.

\section{EVANGELISTS' EMBLEMS.}

St. Matthew, an angel-St. Luke, an ox-St. John, an eagle-St. Mark, a lion. At an early period these emblems were differently attributed.

\section{FOUR DOCTORS OF THE CHURCH.}

St. Jerome, a lion-St. Augustine, a heart-St. Ambrose, a bee-hive or a scourgeSt. Gregory, at Mass, Christ appearing to him over the chalice.

\section{SUBJECTS REPRESENTED COMMONLY IN CHURCHES.}

Seven Cardinal Virtues . . $\left\{\begin{array}{c}\text { Faith, Hope, Charity, Justice, Prudence, Temperance, } \\ \text { and Fortitude. }\end{array}\right.$ Seven Mortal Sins ... \{ Pride, Avarice, Luxury, Envy, Gluttony, Anger, and Allegories, Sundry .... Angels and Archangels, Principalities and Powers, Allegories, SUndRY …

Seven Works of Mercy . Feeding the hungry, Clothing the naked, \&c.

Passion, Instren frown of thorns, nails, hammer, sponge, spear, dice, $i$ lantern, \&c.

(A genealogical tree proceeding from the root of Jesse JESSE ............. 2 (an old Man), our Lord's ancestors being represented ( in the branches.

WheEl of Fortune ...... A large wheel with a crowned female figure in centre, I some rising, others falling from it

S Baptism, Confirmation, Penance, Eucharist, Orders, HeLL . . . . . . A A many-headed monster, vomiting fire.

** In an ensuing Number it is intended to give the converse of the foregoing Catalogue, the names of Saints being arranged alphabetically, with a more detailed account of the Synıbols, and references to existing representations, especially in our own country.

n Sometimes a basket. 